\title{
Clone selection in the Lonicera tatarica complex
}

\author{
SATU TEGEL \\ Dept of Horticulture, University of Helsinki \\ SF-00710 Helsinki, Finland
}

\begin{abstract}
Old clones of Lonicera tatarica L. were registered in four places in Finland in order to find beautiful, hardy and healthy clones. The number of registered clones was 90 ; the 14 best clones were selected for further investigations. Seven of the selected clones were L. tatarica, four with red flowers and three with white flowers. Six of the clones were $L . x$ bella Zabel and one $L$. x notha Zabel. Many of the clones registered as $L$. tatarica proved to be hybrids; these hybrids were, however, often as valuable as ornamentals as $L$. tatarica. $L$. tatarica proved variable and susceptible to pests and pathogens, and it also seemed to hybridize readily with other species. Because of these facts clonal selection of $L$. tatarica clones in cultivation is justified. The real value of the 14 selected clones of the $L$. tatarica complex will be detected in a clone selection trial.
\end{abstract}

Index words: Lonicera tatarica, Lonicera x bella, Lonicera x notha, honeysuckles, clone selection, woody ornamentals, hybridization

\section{Introduction}

Lonicera tatarica $\mathrm{L}$. is one of the oldest ornamentals in Finland (PARVela 1930). It is hardy in the whole country and it is nowadays one of our most common ornamental shrubs (Kallio 1966). It is often considered the most valuable species of the genus (eg. WYMAN 1954). As an ornamental, L. tatarica has, however, many weaknesses. The species is very susceptible to plant diseases and pests (BRANDER 1978). It is also so variable that only the best forms should be selected (BEAN 1973). Habit of growth, flower size and colour, leaf size, health and growing value of the plants vary from one plant to another (GREEN 1966). Especially when propagated from seed, this variation is easily seen in the characters of the planting material.

Cultivation apart, hybridization has been very intensive in the group around $L$. tatarica (the L. tatarica complex). Back-crossing and triple hybridization have also taken place and the result today is that many honeysuckles resembling $L$. tatarica are hybrids. These hybrids are often valuable ornamentals but difficult to identify because they resemble each other so much. The main difference between 
L. tatarica and its hybrids is that L. tatarica is glabrous and its hybrids more or less hairy. (GREEN 1966) It has been evident that also in Finland many bushes cultivated as $L$. tatarica in old plantings and nurseries are hybrids.

Because of these problems the genus Lonicera was the first one to start with in order to improve the quality of the nursery stock in Finland by using selected clones for mother plants. The research was suggested and financed by the Production Unit for Healthy Plants, Agricultural Research Centre. The aim was to register $L$. tatarica clones and to collect beautiful, healthy and hardy ones. Another aim was to study the variation in the $L$. tatarica complex, to see if there are many hybrids in cultivation and to find the growing value of these hybrids. The research was done in summer 1983 and, as a result, 14 clones of the $L$. tatarica complex were selected and propagated for further investigations. Seven of these clones were real $L$. tatarica and seven were hybrids.

\section{Material and methods}

In order to find beautiful, hardy and healthy L. tatarica clones, bushes in old plantations of four cities, Helsinki $\left(60^{\circ} 14^{\prime} \mathrm{N}\right)$, Turku $\left(60^{\circ} 26^{\prime} \mathrm{N}\right)$, Tampere $\left(61^{\circ} 30^{\prime} \mathrm{N}\right)$ and Oulu $\left(65^{\circ} 00^{\prime} \mathrm{N}\right)$, were studied (Figure 1). The research was suggestive of the Danish preliminary tests (BRANDER 1982) and the Norwegian clone collecting phase (HORNTVEDT 1979), where clones were selected for final clone selection tests.

At first the clones were located. The following step was the registration of the characters of different clones several times during the summer. Registration gave knowledge of the variation and characters of the Lonicera tatarica complex and the best clones were selected and propagated (Figure 2). However, most of the bushes were merely located; only the clones with growing value of any kind were registered as well. All the different clones were registered no more than once.

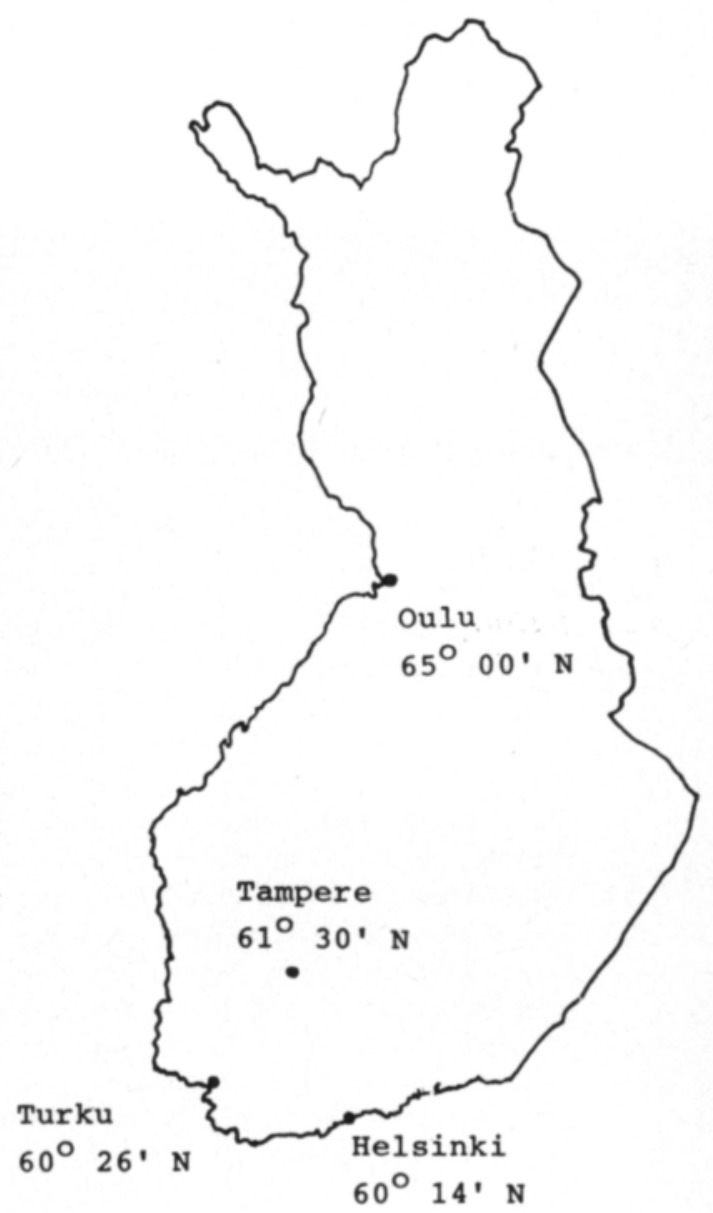

Figure 1. Locations visited during the present study.

LOCATION OF THE BUSHES

- registration of the growing place

- numbering of the clones

REGISTRATION OF THE CHARACTERS

- morphological characters

- growing value

SELECTION OF CLONES

- propagation

Figure 2. Scheme of the research

Registration of characters was done four times in Helsinki and twice in the other places. In Helsinki plants were registered before leafing, during flowering, in mid-summer, and in 
Table 1. Morphological characters registered.

\begin{tabular}{ll}
\hline $\begin{array}{l}\text { Part of } \\
\text { plant }\end{array}$ & Character \\
\hline Leaves & $*$ Leaf shape \\
& $*$ Apex shape \\
& $*$ Base shape \\
& $*$ Gloss \\
& $*$ Length $(\mathrm{cm})$ \\
& $*$ Width $(\mathrm{cm})$ \\
Flowers & $*$ Length of the corolla tube $(\mathrm{mm})$ \\
& $*$ Colour \\
Berries & $*$ Size mm $\varnothing$ \\
& $*$ Gloss \\
\hline
\end{tabular}

autumn while the berries were ripe. In the other places plants were registered during flowering and in autumn.

The following characters were registered: size, habit of growth, leaves, flowering, berries, health and general impression during the summer. The registration was split into two parts. The first part was measurable characters, where morphological characters of the clones were divided into categories by type (Table 1), and the second part was estimated characters (growing value registered by points) (Table 2). All the clones were described in words as well.
Because the registered clones were growing under different conditions, the most promising clones were not always the ones with the highest possible growing value points. Therefore the selected clones were the ones which were presumed to be valuable when growing under favourable conditions. As in Denmark in corresponding researches (BRANDER 1982), the most important character in selection was, however, health. The aim of the selection was to select as many different valuable types of flowering, habit of growth etc. as possible.

Herbarium samples were taken of all the registered clones. The determination of the species was afterwards based on these samples. Herbarium samples are preserved in the collections of the Botanical Museum of Helsinki University. The fungus samples were identified at the Department of Plant Pathology, Agricultural Research Centre, by Päivi Parikka.

\section{Results}

\section{Identification}

The number of registered and indentified clones was 90.78 of these clones were identi-

Table 2. Estimated characters registered. Scale $1-5$ or $1-10,5$ or 10 being the best in terms of growing value.

\begin{tabular}{|c|c|c|c|}
\hline $\begin{array}{l}\text { Group of } \\
\text { characters }\end{array}$ & Character & Scale & Remarks \\
\hline Size & $\begin{array}{l}\text { * Height m } \\
* \text { Width m }\end{array}$ & & \\
\hline Health & & $1-5$ & $\begin{array}{l}\text { Insects and diseases were specified if } \\
\text { possible }\end{array}$ \\
\hline Habit of growth & * Density & $1-5$ & \\
\hline Leaves & $\begin{array}{l}* \text { Density } \\
* \text { Appearance }\end{array}$ & $\begin{array}{l}1-5 \\
1-5\end{array}$ & \\
\hline Flowering & $\begin{array}{l}* \text { Abundance } \\
* \text { Appearance }\end{array}$ & $\begin{array}{l}1-10 \\
1-5\end{array}$ & \\
\hline Berries & $\begin{array}{l}* \text { Abundance } \\
* \text { Appearance }\end{array}$ & $\begin{array}{l}1-10 \\
1-5\end{array}$ & \\
\hline General impression & $\begin{array}{l}* \text { Habit of growth } \\
* \text { Flowering } \\
* \text { Mid-summer } \\
\text { impression } \\
* \text { Autumn impression }\end{array}$ & $\begin{array}{l}1-10 \\
1-10 \\
1-10 \\
1-10\end{array}$ & $\begin{array}{l}\text { Shape, density } \\
\text { Habit of growth, flowering, leaves, } \\
\text { health } \\
\text { Habit of growth, leaves, health } \\
\text { Habit of growth, leaves, berries, health }\end{array}$ \\
\hline
\end{tabular}


Table 3. Morphological characters: The $L$. tatarica, $L . \times$ bella and $L . \times$ notha clones in different categories. $L$. tatarica clones with red and white flowers are handled separately.

\begin{tabular}{|c|c|c|c|c|c|c|c|c|c|}
\hline \multirow{3}{*}{$\begin{array}{l}\text { Part of } \\
\text { plant }\end{array}$} & \multirow[b]{3}{*}{ Character } & \multicolumn{4}{|c|}{ L. tatarica } & & & & \\
\hline & & \multicolumn{2}{|c|}{ White fl. } & \multicolumn{2}{|c|}{ Red fl. } & \multicolumn{2}{|c|}{ L. $x$ bella } & \multicolumn{2}{|c|}{ L. $x$ nothe } \\
\hline & & $\%$ & $\overline{\mathrm{n} .}$ & $\%$ & n. & $\%$ & n. & $\%$ & $\mathrm{n}$. \\
\hline \multirow[t]{10}{*}{ Leaves } & SHAPE & & & & & & & & \\
\hline & oblong & 33.3 & 3 & - & - & 7.1 & 1 & - & - \\
\hline & elliptic & 44.4 & 4 & 17.8 & 8 & 50.0 & 7 & 40.0 & 4 \\
\hline & ovate & 55.6 & 5 & 88.9 & 40 & 78.6 & 11 & - & - \\
\hline & obovate & 44.4 & 4 & - & - & - & - & - & - \\
\hline & lanceolate & 33.3 & 3 & 42.2 & 19 & 57.1 & 8 & 90.0 & 9 \\
\hline & GLOSS & & & & & & & & \\
\hline & glossy & - & - & - & - & - & - & 10.0 & 1 \\
\hline & intermediate & - & - & 8.9 & 4 & 42.8 & 6 & 60.0 & 6 \\
\hline & mat & 100 & 9 & 91.1 & 41 & 57.2 & 8 & 30.0 & 3 \\
\hline \multirow[t]{12}{*}{ Flowers } & COROLLA LENGTH & & & & & & & & \\
\hline & $11-15 \mathrm{~mm}$ & 22.2 & 2 & 33.3 & 15 & 21.4 & 3 & 100 & 10 \\
\hline & $16-20 \mathrm{~mm}$ & 44.4 & 4 & 53.3 & 24 & 42.9 & 6 & - & - \\
\hline & $21-25 \mathrm{~mm}$ & 33.3 & 3 & 11.1 & 5 & 35.7 & 5 & - & - \\
\hline & $26-30 \mathrm{~mm}$ & - & - & 2.2 & 1 & - & - & - & - \\
\hline & $\begin{array}{l}\text { FLOWER COLOUR } \\
\text { white }\end{array}$ & 100 & 9 & - & - & 28.6 & 4 & 10.0 & 1 \\
\hline & pink & - & - & 55.6 & 25 & 7.1 & 1 & - & - \\
\hline & rosy pink & - & - & 31.1 & 14 & 50.0 & 7 & - & - \\
\hline & dark pink & - & - & 4.4 & 2 & 7.1 & 1 & - & - \\
\hline & very light pink & - & - & 8.9 & 4 & 7.1 & 1 & 90.0 & 9 \\
\hline & 2-coloured & - & - & 17.8 & 8 & 71.4 & 10 & 90.0 & 9 \\
\hline & turning yellow & 22.2 & 2 & 15.6 & 7 & 35.7 & 5 & 100 & 10 \\
\hline \multirow[t]{11}{*}{ Berries } & SIZE $\varnothing$ & & & & & & & & \\
\hline & small $(4-7 \mathrm{~mm})$ & 22.2 & 2 & 34.1 & 15 & - & - & 40.0 & 4 \\
\hline & interm. $(6-8 \mathrm{~mm})$ & 33.3 & 3 & 54.5 & 24 & 7.7 & 1 & 30.0 & 3 \\
\hline & large $(7-10 \mathrm{~mm})$ & 44.4 & 4 & 11.4 & 5 & 92.3 & 12 & 30.0 & 3 \\
\hline & COLOUR & 333 & 3 & 227 & 10 & 538 & 7 & $\ldots$ & - \\
\hline & red & 44.4 & 4 & 70.5 & 31 & 38.5 & 5 & 60.0 & 6 \\
\hline & dark red & 22.2 & 2 & 6.8 & 3 & 7.7 & 1 & 40.0 & 4 \\
\hline & GLOSS & & & & & & & & \\
\hline & glossy & 88.9 & 8 & 90.9 & 40 & 92.3 & 12 & 40.0 & 4 \\
\hline & intermediate & 11.1 & 1 & 2.2 & 1 & - & - & 40.0 & 4 \\
\hline & mat & - & - & 6.8 & 3 & 7.7 & 1 & 20.0 & 2 \\
\hline \multicolumn{2}{|c|}{ Number of reg. clones } & \multicolumn{2}{|c|}{9} & \multicolumn{2}{|c|}{45} & \multicolumn{2}{|c|}{14} & \multicolumn{2}{|c|}{10} \\
\hline
\end{tabular}

fied. 54 of the identified clones were $L$. tatarica. 14 of the clones were $L$. x bella Zabel $(L$. morrowii A. Grey x L. tatarica); four clones of $L$. x bella were a Canadian variety 'Dropmore'. 10 of the clones were $L$. x notha Zabel (L. ruprechtiana Regel x L. tatarica). The rest of the clones could not be identified. These clones had no particular growing value and they were excluded from the research. $L$. tatarica was registered in all of the places in- vestigated, $L . \times$ bella in Helsinki, Tampere and Oulu and L. x notha in Helsinki and Tampere.

\section{Morphological characters}

Morphological variation in the complex was remarkable. Variation occurred both within and between the species.

Leaf shape of the clones was variable. The 
shape of the leaves of the white-flowered $L$. tatarica was often different from that of the red-flowered. The leaves of $L$. tatarica and $L$. $\mathrm{x}$ bella were rather similar, L. x notha had leaves different from both the other species: they were usually lanceolate.

The size, form and colour of flowers was highly variable. The flower colour varied from white to different shades of red. The rarest flower colour was dark red. Many of the flowers were two-coloured: the lobes were margined with lighter or darker stripes. All the flowers of $L . x$ notha turned yellow when fading. So did some of the flowers of $L$. x bella and even four of $L$. tatarica. The size of the flowers of $L$. tatarica varied a lot, the biggest flowers being $28 \mathrm{~mm}$. L. x notha bore the smallest flowers $(10-15 \mathrm{~mm})$. The corolla lobes of $L$. tatarica were usually wider than those of the hybrids.

The colour of the berries was orange, red or dark red. L. x bella bore the largest berries. The colour of the flowers and berries did not correlate.

\section{Growing value}

The habit of growth of the registered clones was rather poor. With L. tatarica it varied a lot, but most of the clones were high and sparse. The habit of growth of $L$. x bella was very much like $L$. tatarica but more often widespreading. L. x bella 'Dropmore' was very broad, dense and wide-spreading.

The appearance of leaves was also rather poor. This was often a result of the attack of pests and diseases.

Most of the bushes were very richly flowering, especially those of L. x bella. L. x notha was less floriferous than the others and, as its flowers where also rather small and light in colour, the bushes were less showy when flowering than the others. The amount of berries was usually smaller than that of flowers. The amount of berries was largest among $L$. $\mathrm{x}$ bella. Especially orange berries were very showy.

The general impression of the bushes was rather poor in spite of the showy flowering. Especially the habit of growth and health of the bushes were poor. Only five bushes of $L$. tatarica were healthy. Several bushes had leaf spots and almost half of L tatarica bushes were attacked by powdery mildew (Microsphaera lonicerae (DC. ex St.-Amans) Winter). Different clones of L. tatarica showed different susceptibility to mildew even when grown closely. On $L . \mathrm{x}$ bella and $L . \mathrm{x}$ notha powdery mildew was not observed.

When white- and red-flowered $L$. tatarica bushes were examined separately, it was noticed that the growing value of the whiteflowered $L$. tatarica clones was often better than that of the red-flowered ones. With whiteflowered bushes the given points of health, habit of growth, leaf density and appearance, floriferousness, amount of berries and general impression were usually higher than those of the red-flowered ones.

\section{Clone selection}

The aim of the selection was to find clones that have all the good properties that make the taxa of the Lonicera tatarica complex worth cultivating: good health, rich flowering, large, beautiful-coloured, broad-lobed flowers, handsome leaves, large berries and a good habit of growth. Clones like this were, however, not easy to find. Especially difficult was it to find clones that were healthy.

Most of the clones were unsuitable because of poor health. Most of the remaining clones were unsuitable because of the poor habit of growth. Of the remaining clones, the 14 most promising ones were selected. Seven of them were $L$. tatarica, 3 with white flowers and 4 with red flowers. Six of the clones were $L$. x bella and one was $L$. x notha.

\section{Selected clones}

\section{3 - L. tatarica, Helsinki}

The most important character of clone 193 was its immunity to powdery mildew. It was one of the healthiest $L$. tatarica bushes found: 
Table 4. Estimated growing value characters: L. tatarica, $L . \times$ bella and $L . \times$ notha clones in different categories. The highest category is always the best in terms of growing value.

\begin{tabular}{|c|c|c|c|c|c|c|c|c|c|}
\hline \multirow[b]{3}{*}{ Character } & \multirow[b]{3}{*}{ Category } & \multicolumn{4}{|c|}{ L. tatarica } & \multirow{2}{*}{\multicolumn{2}{|c|}{ L. $x$ bella }} & \multirow{2}{*}{\multicolumn{2}{|c|}{ L. $x$ notha }} \\
\hline & & \multicolumn{2}{|c|}{ White fl. } & \multicolumn{2}{|c|}{ Red fl. } & & & & \\
\hline & & $\%$ & $\mathrm{n}$. & $\%$ & n. & $\%$ & $\mathrm{n}$. & $\%$ & n. \\
\hline \multirow{4}{*}{$\begin{array}{l}\text { Habit of } \\
\text { growth } \\
(1-10)\end{array}$} & $3-4$ & 11.1 & 1 & 9.3 & 4 & - & - & - & - \\
\hline & $5-6$ & 33.3 & 3 & 53.5 & 23 & 57.1 & 8 & 50.0 & 5 \\
\hline & $7-8$ & 22.2 & 2 & 32.6 & 14 & 28.6 & 4 & 40.0 & 4 \\
\hline & $9-10$ & 33.3 & 3 & 4.7 & 2 & 7.1 & 1 & 10.0 & 1 \\
\hline \multirow{4}{*}{$\begin{array}{l}\text { Habit of } \\
\text { growth: } \\
\text { Density } \\
(1-5)\end{array}$} & 2 & - & - & 2.2 & 1 & 14.3 & 2 & 10.0 & 1 \\
\hline & 3 & 33.3 & 3 & 46.7 & 21 & 35.7 & 5 & 60.0 & 6 \\
\hline & 4 & 33.3 & 3 & 35.6 & 16 & 35.7 & 5 & 30.0 & 3 \\
\hline & 5 & 33.3 & 3 & 15.6 & 7 & 14.3 & 2 & - & - \\
\hline \multirow{4}{*}{$\begin{array}{l}\text { Leaf } \\
\text { density } \\
(1-5)\end{array}$} & 2 & 11.1 & 1 & 15.6 & 7 & 14.3 & 2 & - & - \\
\hline & 3 & 11.1 & 1 & 40.0 & 18 & 14.3 & 2 & 30.0 & 3 \\
\hline & 4 & 33.3 & 3 & 40.0 & 18 & 50.0 & 7 & 50.0 & 5 \\
\hline & 5 & 44.4 & 4 & 4.4 & 2 & 21.4 & 3 & 20.0 & 2 \\
\hline \multirow{4}{*}{$\begin{array}{l}\text { Leaf } \\
\text { appearance } \\
(1-5)\end{array}$} & 2 & - & - & 13.3 & 6 & 7.1 & 1 & 10.0 & 1 \\
\hline & 3 & 33.3 & 3 & 60.0 & 27 & 42.9 & 6 & 20.0 & 2 \\
\hline & 4 & 55.6 & 5 & 22.2 & 10 & 42.9 & 6 & 60.0 & 6 \\
\hline & 5 & 11.1 & 1 & 4.4 & 2 & 7.1 & 1 & 10.0 & 1 \\
\hline \multirow{5}{*}{$\begin{array}{l}\text { Flowering: } \\
\text { abundance } \\
(1-10)\end{array}$} & $1-2$ & - & - & 2.2 & 1 & - & - & - & - \\
\hline & $3-4$ & - & - & 4.4 & 2 & - & - & - & - \\
\hline & $5-6$ & 22.2 & 2 & 15.6 & 7 & - & - & 10.0 & 1 \\
\hline & $7-8$ & 44.4 & 4 & 46.7 & 21 & 21.4 & 3 & 70.0 & 7 \\
\hline & $9-10$ & 33.3 & 3 & 31.1 & 14 & 78.6 & 11 & 20.0 & 2 \\
\hline \multirow{5}{*}{$\begin{array}{l}\text { Berries: } \\
\text { abundance } \\
(1-10)\end{array}$} & $1-2$ & 33.3 & 3 & 29.5 & 13 & - & - & - & - \\
\hline & $3-4$ & 11.1 & 1 & 36.4 & 16 & 14.3 & 2 & 40.0 & 4 \\
\hline & $5-6$ & 33.3 & 3 & 22.7 & 10 & 21.4 & 3 & 20.0 & 2 \\
\hline & $7-8$ & 22.2 & 2 & 11.4 & 5 & 28.6 & 4 & 40.0 & 4 \\
\hline & $9-10$ & - & - & - & - & 28.6 & 4 & - & - \\
\hline \multirow{3}{*}{$\begin{array}{l}\text { General } \\
\text { impression: } \\
\text { average of } \\
4 \text { reg. }(1-10)\end{array}$} & $4-5.9$ & 11.1 & 1 & 28.9 & 13 & - & - & 10.0 & 1 \\
\hline & $6-7.9$ & 55.6 & 5 & 66.7 & 30 & 71.4 & 10 & 80.0 & 8 \\
\hline & $8-10$ & 33.3 & 3 & 4.4 & 2 & 28.6 & 4 & 10.0 & 1 \\
\hline \multirow{4}{*}{$\begin{array}{l}\text { Health: } \\
\text { average of } \\
2 \text { registr. } \\
(1-5)\end{array}$} & $2-2.5$ & - & - & 13.3 & 6 & - & - & - & - \\
\hline & $3-3.5$ & 22.2 & 2 & 44.4 & 20 & 7.1 & 1 & 30.0 & 3 \\
\hline & $4-4.5$ & 44.4 & 4 & 37.8 & 17 & 57.1 & 8 & 50.0 & 5 \\
\hline & 5 & 33.3 & 3 & 4.4 & 2 & 35.7 & 5 & 20.0 & 2 \\
\hline \multicolumn{2}{|c|}{ Number of reg. clones } & \multicolumn{2}{|c|}{9} & \multicolumn{2}{|c|}{45} & \multicolumn{2}{|c|}{14} & \multicolumn{2}{|c|}{10} \\
\hline
\end{tabular}

it had neither pests nor pathogens. Its leaves were very beautiful. The bush was very richly flowering and it bore pink, rather small (12 $\mathrm{mm}$ ) flowers and orange berries.

\section{1 - L. tatarica, Helsinki}

The clone bore rosy-pink two-coloured flowers with a dark red middle stripe. The clone showed a slight susceptibility to powdery mildew. The foliage was dense and dark. The bush was very richly flowering; flowers were large $(18-20 \mathrm{~mm})$ and fragrant, the berries were red.

\section{1 - L. tatarica, Helsinki}

Clone 481 was the most beautiful clone of the pink-flowered $L$. tatarica. Its leaves were exceptionally handsome. It bore, however, rather small flowers and it also showed a slight susceptibility to powdery mildew. The habit of growth was good: it was rounded and dense. The flowers were middle size $(15 \mathrm{~mm})$ and 
pink; the corolla lobes were rounded and very wide. The berries were red.

\section{9 - L. tatarica, Helsinki}

Clone 509 bore the darkest flowers of the species. Its leaves were also beautiful; it showed a susceptibility to powdery mildew. It was a wide, dense shrub with dense and handsome foliage. The flowers were rather large (16-18 mm), two-coloured and very dark red. The berries were red.

\section{7 - L. tatarica, Helsinki}

Clone 177 bore large, pure white flowers, and it was the most valuable of the L. tatarica found. Especially its regular habit of growth was the best of all. It showed some susceptibility to powdery mildew. The bush was rounded, dense and very regular in shape. The foliage was dense and bluish green. The bush was richly flowering and the flowers were large (20 $\mathrm{mm}$ ) and pure white with wide corolla lobes. The berries were red.

\section{7 - L. tatarica, Turku}

Clone 677 was rather exceptional: its leaves, flowers and berries were unusually thick or large. The bush showed no susceptibility to pests or diseases. The leaves were thick and bluish green. The flowers were pure white, large $(25 \mathrm{~mm})$, with very broad $(6 \mathrm{~mm})$ corolla lobes. The berries were large $(9-12 \mathrm{~mm} \mathrm{Ø)}$ and orange in colour.

\section{$708-$ L. tatarica, Oulu}

Clone 708 was the third selected clone with white flowers; it resembles 677 to some extent. It was wide-spreading and, growing in deep shade, rather sparse. The leaves were large, grayish and thick. The flowers were large ( 22 $\mathrm{mm}$ ) and white with a tinge of red in the buds. The bush bore a lot of orange berries. The bush had neither pests nor diseases.

\section{4 - L. x bella, Helsinki}

Clone 194 was very richly flowering and healthy; it resembles 541. It was wide-spreading and somewhat irregular in shape. The leaves were large and rather glossy. The flowering was very abundant and showy, the flowers being large ( $20-22 \mathrm{~mm})$, rosy-pink and twocoloured with a darker middle stripe. The bush bore abundantly large, orange berries.

\section{1 - L. x bella, Helsinki}

Clone 541 was very richly flowering. The bush was high and dense but rather irregular in shape. The foliage was dense and dark. The bush was one of the richest in flowering of all the registered honeysuckles, the flowers were large (20-22 $\mathrm{mm})$ and rosy-pink with a darker middle stripe. The bush bore a large number of orange berries. The bush had no pests but showed a slight susceptibility to leaf spots.

\section{1 - L. x bella 'Dropmore', Helsinki}

Clone 571 was a high and wide-spreading, very floriferous shrub with a large amount of berries. The leaves were very small but the foliage was dense. The flowers were white with curling lobes, small $(13 \mathrm{~mm})$, and turned yellow when fading. The berries were large and red. The bush showed no susceptibility to pests or diseases.

\section{4 - L. x bella, Helsinki}

Clone 664 had a light foliage, rather exceptional flowers and good health. The bush was vigorous and rich in blossom. The flowers were light pink with a white middle stripe; the berries were red. The bush had neither pests nor diseases.

\section{7 - L. x bella, Tampere}

Clone 687 had an unusual habit of growth and very dark flowers. The bush was low, wide-spreading and very dense. The leaves were thick, dark and hairy. The bush was richly flowering; the flowers were rather large $(20$ $\mathrm{mm}$ ), fragrant and two-coloured dark red with curling lobes. The berries were also large and the colour was red. The bush had no pathogens but showed signs of aphids and leaf mining insects. 
712 - L. x bella, Oulu

Clone 712 was a vigorous, healthy shrub with beautiful foliage. It was rather irregular in shape. The leaves were grayish green and slightly glossy. The flowering was abundant; the flowers were similar to those of clones 194 and 541. The bush bore a lot of shiny, orange berries. The bush had no diseases but showed signs of mites and leaf mining insects.

\section{4 - L. x notha, Helsinki}

Clone 524 was a healthy bush with a regular habit of growth and a beautiful foliage. The flowering was rather undistinguished. The shoots were thick and short. The leaves were rather large $(5-9 \mathrm{~cm})$ and light green. The bush was rich in inflorescence, but the flowers were small $(13 \mathrm{~mm})$ and light pink in colour. They were two-coloured and turned dull yellow when fading. The berries were red.

\section{Discussion}

\section{Identification}

As expected, many bushes cultivated as $L$. tatarica proved to be hybrids. GREEN (1966) reports the same phenomenon in the USA. Some of the hybrids could not be identified even with the help of a key constructed by GREEN (1966); these hybrids were probably backcrossings or triple hybrids.

The identification of some clones was uncertain. The flowers of four L. tatarica clones turned yellow when fading; this, according to Green (1966), means that the clones were hybrids. The flowers of some $L$. x bella clones, however, lacked the tendency to turn yellow when fading. This tendency, according to GREEN (1966), decreases the growing value of L. tatarica hybrids. Thus, the lacking tendency of the flowers to turn yellow increases the growing value of these $L . \mathrm{x}$ bella clones but shows that they are not real $L$. x bella. It is probable that they are backcrossings between $L$. $\mathrm{x}$ bella and $L$. tatarica that have retained the floriferousness and hairiness of $L . \mathrm{x}$ bella but lost the tendency for the flowers to turn yellow. It would seem justified to give these clones (e.g. 194, 541, 664, 712) merely a variety name.

\section{Variation}

The L. tatarica complex proved highly variable. This was expected, because $L$. tatarica itself is highly variable (GREEN 1966) and as the hybridization has been taking place between very variable clones, the hybrids are variable as well.

According to Brander (1978), L. tatarica is highly susceptible to pests. In this research, however, diseases decreased the general impression of the bushes more clearly than pests. Especially powdery mildew was harmful. In 1983 , powdery mildew was very common in Finland also on cereals and berries (MARKKULA 1984). In the $L$. tatarica complex, only $L$. tatarica was susceptible to powdery mildew; on hybrids it was not observed. It is uncertain if this phenomenon is detected anywhere else. The hybrids seem also more resistant to other diseases than L. tatarica.

\section{Growing value}

L. tatarica is considered the most valuable species in the $L$. tatarica complex (GREEN 1966). In the present study, the growing value of the L. tatarica clones was surprisingly low. The species was, however, variable as to the growing value. Anyway, as a species L. tatarica was very susceptible to pests and diseases and its habit of growth was often poor. Also e.g. Olsen (1976) and Brander (1978) report the same thing. As ornamentals $L$. tatarica clones with white flowers were more valuable than the ones with red flowers. This has been noticed also in Norway (ANON. 1985) and in Denmark (BRANDER 1982). Contrary to the opinion of GREEN (1966), the hybrids were in the present study often more valuable than $L$. tatarica. 


\section{Selected clones}

Some of the selected clones of the complex appear to be valuable as ornamentals. Unlike in Denmark, where they could not select any red-flowered $L$. tatarica clones worth cultivation (BRANDER 1982), in this study also some of the L. tatarica clones with red flowers appear to be valuable. Especially clones 351, 481 and 509 may prove to be more valuable than the L. tatarica 'Rosea' commonly cultivated in Finland, if they only are found healthy enough. Clone 177 appears to be very promising; L. tatarica clones with white flowers have not been propagated in the Finnish nurseries so far. The $L$. x bella clones selected resemble each other to some extent, but some of the clones may prove to be worth cultivation, e.g. clone 541 . Also the only L. x notha clone (524) may be valuable. In the other Nordic countries, no $L$. tatarica hybrid clones have been selected. For example, in the Danish literature there are no reports of the L. tatarica hybrids; it may be that the frequency of hybridization around $L$. tatarica has not yet been noted in Denmark.

Because the clones selected now were growing under such different conditions, their real value can be detected only in a clone selection trial. A clone selection trial with the best collected clones is planned to be started in 1987.

\section{Conclusions}

The problems with the $L$. tatarica complex in cultivation proved to be the intensity of hybridization, the considerable variation and the lack of health. The many hybrids are so difficult to discern from the real $L$. tatarica that it is probable that $L$. tatarica clones in Finnish nurseries, especially when propagated from seed, are often of hybrid origin. There is, however, no reason to avoid cultivating these $L$. tatarica hybrids: they are vigorous and richly flowering. Another benefit of the hybrids is their good health: they appear to be resistant to powdery mildew. They also appear to be more resistant to other diseases than L. tatarica. These hybrids should, in any case, be named correctly.

As $L$. tatarica complex hybridizes so readily and is so variable, seed propagation of this group should be avoided and the clones in cultivation should be selected carefully. Clone selection can be affected by e.g. habit of growth, abundance, size and colour of the flowering and foliage. Also the varying susceptibility of clones to pests and diseases increases the importance of clone selection of this horticulturally important complex.

\section{References}

BEAN, W.J. 1973. Trees and shrubs hardy in the British Isles 2. 784 p. 8th Ed. London.

Brander, P.E. 1978. Lonicera L. Havens planteleksikon 1: 346-356. Tønder.

- 1982. Investigation concerning clone selection of trees and shrubs used for ornamental and landscaping purposes. Tidsskr. Pl.avl 86: 241-254.

GREen, P.S. 1966. Identification of the species and hybrids in the Lonicera tatarica complex. J. Arnold Arboretum 47: 75-88.

HoRntVEDT, S. 1979. Utvalg av gode typer av prydtraer og busker. Ảrsskr. Pl.skoledrift Dendr. 23-25; 101105.

KALıo, T.K. 1966. Koristepuiden ja -pensaiden levinneisyydestä ja menestymisestä Suomessa. Ann. Agr. Fenn. 5: 1-107.

MARKKULA, I. 1984. Kasvitaudit vuonna 1983. Koetoim. ja Käyt. 41: 2.

OLsen, C-C. 1976. Traeer og buske i laehegn. Tidsskr. Pl.avl. 80: 642-650.

PARvela, A.A. 1930. Oulun lăănin viljelykasvit, niiden historia ja nykyinen levinneisyys I. Yleinen osa. Ann. Soc. 'Vanamo' 13, 1: 1-354 p.

Wrman, D. 1954. Shrubs and vines for American gardens. 442 p. 3rd Ed. New York.

ANON. 1985. Suksess for Nord-Norsk Plantemateriale. Gartn.yrket 75: 156, 158.

Ms received May 18, 1987 


\section{Rusokuusama-ryhmän (Lonicera tatarica -ryhmä) viljelykantojen rekisteröinti ja valinta}

\section{Tegel, S.}

\section{Helsingin yliopisto, Puutarhatieteen laitos $00710 \mathrm{Helsinki}$}

Vanhojen istutusten rusokuusamakantoja tutkittiin kauniiden, terveiden ja kestävien kantojen löytämiseksi. Istutuksia tutkittiin neljällä eri paikkakunnalla. Erilaisia kantoja rekisteröitiin $90 \mathrm{kpl}$. Kantojen lajinmäärityksessä osoittautui, että hyvin monet rusokuusamina rekisteröidyt kannat olivat erilaisia rusokuusaman hybridejä. Rekisteröidyistả kannoista 14 lupaavinta valittiin jatkotut- kimuksiin. Valituista kannoista 7 oli aitoja rusokuusamia (L. tatarica L.), neljä punakukkaista ja kolme valkokukkaista. Kuusi kantaa oli sirokuusamia ( $L$. x bella Zabel) ja yksi perhokuusama (L. x notha Zabel).

Rusokuusama ( $L$. tatarica) osoittautui voimakkaasti muuntelevaksi, terveydentilaltaan huonoksi ja alttiiksi risteytymäăn lähilajiensa kanssa. Risteytymien tuloksena syntyneet hybridit ( $L . \times$ bella ja $L$. x notha) olivat kuitenkin usein koristearvoltaan aivan rusokuusaman veroisia, mm. terveydentilaltaan jopa sitä parempia: nämä risteymăt eivät näytä olevan alttiita kuusamanhärmälle. Rusokuusamaryhmän lajit năyttävăt siis olevan viljelemisen arvoisia; tosin viljellyt kannat on syytä valita huolellisesti ja lisätä niitä vain vegetatiivisesti. Nyt valittujen 14 kannan todellinen arvo selviää vasta tulevissa vertailevissa kenttäkokeissa. 